\title{
Critico-analytic Study of ESP Final Exam Tests for Students of Accounting in Iranian Universities
}

\author{
Farnaz Latif \\ Department of English Language, Shahr-e-Rey Branch, Islamic Azad University, Tehran, Iran \\ Mahdieh Shafipoor \\ Department of English Language Translation, Shahr-e- Qods Branch, Islamic Azad University, Tehran, Iran
}

\begin{abstract}
Assessing learners has constantly played a considerable role in teaching and learning process. This significance is obviously observed in teaching foreign languages in general and teaching English for specific purposes (ESP) in particular. Since in the global community, English language is considered as the major medium in techno- scientific communications and interactions, the demand for academic considerations for teaching and developing ESP as a central interdisciplinary course is increasingly growing. This growing tendency has created opportunities for designing and developing various technical and special course materials around the globe. In Iran, as well as the other countries, this movement has been with the main objective of promoting the quality of teaching reading comprehension skills along with translation techniques into the native language and developing relevant technical terminologies in every major. However, still a sort of inconsistency among teaching ESP, publishing ESP materials, and developing final exam ESP tests exists. This inconsistency emerged as the role of ELT specialists in each of the above mentioned activities disqualified the educational values of teaching and learning ESP. Although the administrators and authorities have allocated great amount of budget to designing, developing and holding courses, as well as ESP instructors' payments, still the quality and the efficiency is not as high as expected. Thus, considering the existing gap, the researchers in the present study have attempted to critically study and analyze the final exam tests of ESP for students of accounting in Islamic Azad University, Shahr-e- Rey branch, in Tehran in order to highlight the current problems and propose practical solutions in this regard.
\end{abstract}

Index Terms - ESP (English for Specific Purposes), testing, ELT, learning

\section{INTRODUCTION}

Since early 60s research in ESP has considerably drawn the attention of scholars in the field so that it has emerged among the most prominent areas in TEFL. In fact, in line with the emergence of ESP, heavy demands for testing specific groups of learners have been observed. Therefore, reviewing the demand and growth in ESP testing point out a rather slow but definite trend over the past decade.

Tracing the available literature reviews relevant to ESP testing, one can come across the following three folded classifications.

The first classification refers to a segregated approach toward ESP testing which considers it as a distinctive component of a rather general movement of ELT (English Language Testing). In other words, it concentrates on measuring particular uses of English Language among specified target groups of people in different fields such as nursing, medicine, sciences, accounting, law, etc.

The second category reflects on ESP testing in broader context within teaching and learning process. Followers of this approach as Dudley-Evans and St. John (2005) content that assessment is not an individual and independent process. In fact, they believe that assessment entails a crucial position in ESP process through preparing ample information on pedagogical efficacy and quality. Figure 1 depicts the interaction between needs analysis and assessment and the reliance of assessment on syllabus design.

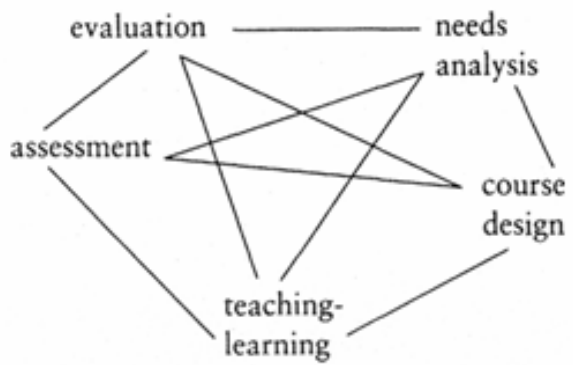

Figure 1: Stages in the ESP process (Dudley-Evans \& St. John, 2005, p. 121) 
Finally, the third classification focuses on the capability of ESP testing as a learning facilitator and device. In fact, an ESP test is "an aid to learning"(Dudley-Evans \& St. John, 2005, p. 212). In addition, assessment can evaluate the advantageous outcome of learning to transfer a sense of triumph and accomplishment to the learners. In other words, they will feel satisfied while they perceive the fact that the instructor's evaluation matches their learned skills and knowledge during the course of study. Thus, at this point, assessment can be defined as an "observed" judgment of pedagogical efficacy (Richards \& Renandya 2002) or as it is stated by Dudley-Evans and St. John (2005) assessment "encompasses benefits such as reinforcement, confidence building, involvement and building on strengths"(p.210).

\section{Characteristics of ESP tests}

ESP testing chiefly entails a facilitative feature to enhance learners' communicative performance (while accomplishing communicative tasks); a critical feature to reflect on the learning process and outcome to confirm the learnt material, highlight the deficiencies; a stimulator to encourage learning and supervise the learners' progress.

Since linguistic performance is context bound and differs from one individual to the other, thus a test taker's success in ESP tests largely depends on the interaction between his/her language knowledge (linguistic competence) and the target ESP content knowledge. In other words, contrary to General English Tests, ESP tests are more likely to be applied for adults or secondary school learners at intermediate and advanced level, or learners who have already acquired and developed basic linguistic competence. According to Douglas (2000) ESP test are "contrived language use events" in which, ideally, the test taker's specific purpose linguistic competence and performance in particular specialized fields are measured(p.10). Thus, the main concern will be whether the target ESP learners can successfully communicate in the target ESP context, employ ESP to reach their objectives, to comprehend and be understood in order to get their message across in English.

ESP tests are language specific. In addition, they ate contextually and thematically associated with a particular discipline. the specificity of the lexical semantic and syntactic characteristics ESP language, along with its communicative function enable learners in a particular academic, professional or vocational field to transfer their message more specifically. Therefore, in ESP testing, tests are developed based on a detailed analysis of contextual and task-based characteristics in target ESP context. So, the target profile for assessing particular ESP learners need to comprise samples of communication activities, communication purposes, linguistic features, functions, descriptions of content areas, language skills, etc. For example, to devise an ESP test for students of nursing, it is essential to describe a range of typical situation in which nurses work, typical uses and characteristics of English language they most often find themselves in. The aforementioned sort of typical authentic communicative events would initially lead to development of appropriate test tasks, secondly, facilitate the development of a more integrated and thematically associated basement which would endure the reliability and validity of such assessment (Douglas 2000; Hutchinson \&Waters 1987; Munby 1978).

ESP tests in general are more concerned with presenting four main language skills in order to evaluate the learners' competence and performance in this regard. In fact, priority and vitality of spoken components to assess learners' competent and performance level in target language in undeniable. However, the key to assessing ESP is to present learners with authentic tasks in connection with the sort of activities they may have to do with the language in real life situations.

In view of what has been discussed, obviously, in an ESP test the purpose, the test content and the methods are narrowly specified. Take an ESP test developed for Architectural Engineers or MBA students to evaluate their occupational language competence. Then, according to Trantik (2008), accepting the characteristics of ESP tests as discussed before probes the number of available ESP tests. In fact, specific purposes can be wide or narrow, vocational or academic, entailing anything from English for Airport Controllers, Chemists or Hoteliers to Legal English and beyond. The observed diversity poses the questions whether ESP testing is really possible between widely differing fields or whether each field of human activity has an ESP test of its own. In general, all human activities and all the specific purposes can face inevitable overlaps (Trantik, 2008). Thus, there is no clear borderline between the beginning of an ESP test and the end of the other one. Tests developed and devised for different fields regardless of diversity in context will definitely share features. This unique characteristic of ESP tests is appealing since the vast repertoire of specific tests developed is also underpinned by a common structure of testing principles and techniques. In this sense, then, ESP testing offers a framework relevant across different disciplines.

\section{Assuring the quality of ESP tests}

When devising an ESP test valid and reliable measures of language ability are required to be developed as well. These measures are expected to be as authentic as possible, provide accurate and reliable measures of language ability, have beneficial impacts, and be practical and cost effective in terms of administration, time, money and personnel. These factors have been identified as quintessential ones which affect the quality of the test positively or negatively (Alderson et al. 1995; Bachman and Palmer 1996; Douglas 2000; Dudley-Evans and St. John 2005).

Taking "authenticity" into account, a qualified devised ESP test should engage the test takers in accomplishing various genuine tasks through which their general English knowledge (linguistic competence) can interact with their ESP content knowledge in a real life and authentic context. Such an interaction is integral to the whole ESP testing process. Here, authentic language and material refer to the language used in non-test or non-pedagogic context which is 
merely based on the readers' needs and language use in natural and real life situations. Thus, authenticity of the tasks refers to the similarity of the task content to the specific and specialized target language situation.

The second important factor which qualifies an ESP test is backwash or washback effect. According to Hughes (1989), the notion explores the relationship between test use and the ESP context within which the test is devised. Simply, it is the impact of testing on classroom instruction on "what is taught and how it is taught" (Dudley-Evans \&St. John, 2005, p. 214).

Important tests may generate positive or negative backwash for the test takers. According to a research carried out by Karim (2002), the relationship between testing and teaching is very sophisticated. He believes that "it is misleading to claim that good tests will automatically have beneficial effects on classroom instruction".

Other factors such as such as teacher competence, motivation and innovation, the climate of the school, socioeconomic status of learners and instructors join to exert an equally vital impact on what occurs in an ESP classroom.

\section{METHOD}

\section{A. Participants}

In the present study, different groups of participants took part in the qualitative phase. At the first stage of the qualitative phase, 9 ESP instructors of accounting were randomly selected to attend the preliminary interview section to collect their ideas concerning the current condition of the ESP course material, their impact on the learning process, and their final evaluation of teaching ESP to students of accounting at their university. At the second stage of the qualitative phase, a questionnaire was developed and distributed among 30 accounting ESP instructors to collect their attitudes and beliefs regarding the quality of the content of ESP course they are teaching, and the consistency of the course contents with the final exam test content.

\section{B. Instruments}

The data collection instruments in the present study include interview questions, a questionnaire and a checklist to study the level of the consistency between accounting ESP course book content, and final exam ESP tests.

\section{Procedure}

The design employed to carry out the present investigation is called -Mixed Method which is a combination of qualitative and quantitative methods. A mixed-methods study encompasses the collection or analysis of both quantitative and qualitative data in a single study with some attempts to integrate two approaches at one or more stages of the research process. In other words, mixed - methods research design involves the mixing of quantitative and qualitative research methods or paradigm characteristics (Johnson \& Christensen 2004).

According to Sandelowski (2003), there are two main and somewhat conflicting purposes for combining methods: (a) to achieve a fuller understanding of a target phenomenon and (b) to verify one set of findings against the other. To this end, in the 1970s, scholars who conduct mixed methods research desired to combine qualitative and quantitative research methods through introduction of a new concept called - Triangulation. The term - Triangulation became synonymous with combining data sources through multiple methods. This method maximizes both the internal and external validity of research and helps reduce the inherent weaknesses of individual methods (Dornyei, 2007).

\section{Qualitative phase}

In the present study, at the very first qualitative stage, a field study was conducted with the following purposes;

1. To study the course materials of accounting ESP classes in Islamic Azad University Shahr-e- Rey branch in Tehran.

2. To collect and study the accounting ESP final exam tests.

Secondly, an interview session was arranged with 9 accounting ESP instructors to explore their conceptualizations toward ESP tests and the consistency with the ESP course syllabus. Then, through the process of content analysis the responses of the instructors were transcribed and coded to develop a checklist in line with the standard checklist presented by Dudley-Evans. T. \& St. John M.J.(2005). Finally, a questionnaire was devised based on the result of the checklist analysis to collect the other accounting ESP instructors' conceptualizations for further generalizations.

\section{Quantitative phase}

The researchers at the second phase, attempted to analyze reliability and validity of accounting ESP final exam tests.

\section{RESULTS}

\section{A. Qualitative Phase}

\section{Stage I: Field Study Report}

At this stage, after interviewing the head of the Accounting department at Islamic Azad University, Shahr-e-Rey the researchers could have access to the required information concerning the employed course materials for accounting ESP classes there. Then, with the support and permission of the dean of the Accounting and Management College, copies of 
the recently administered final exam questions of accounting ESP tests were collected. Finally, via the Central Organization of Islamic Azad University's portal, the researchers could learn that there are no officially announced syllabi for ESP courses in Iranian universities.

\section{Stage II: Interview}

At this stage, 9 university instructors teaching ESP to students of accounting were selected to take part in the interview (Figure2) to explore their conceptualizations regarding teaching and testing ESP in general and the level of the consistency between the officially defined syllabi and the course content in line with final exam tests. After transcribing, coding, and content analysis of a checklist was designed based on standard checklist adopted from DudleyEvans. T. \& St. John M.J.( 2005).

TABLE 2

SEMI-STRUCTURED INTERVIEW QUESTIONS

\begin{tabular}{ll}
\hline 1. How do you select the ESP course materials? \\
2. Explain your classroom assessment techniques. \\
3. How do you allocate scores in every semester (final exam and midterm)? \\
4. What are your criteria for assessing and scoring? \\
5. How free do you act in selecting your assessment techniques? \\
6. What types of questions are appropriate for final exam assessment? \\
7. What do you think of developing translation questions to assess ESP at the final exam? \\
8. What do you think of terminology translation questions to assess ESP at the final exam? \\
9. What do you think of using reading comprehension questions to assess ESP at the final exam? \\
10. What do you think of using multiple choice questions to assess ESP at the final exam?
\end{tabular}

\section{Stage III: Checklist Report}

In order to prepare a checklist with the purpose of studying the accounting ESP final exam tests, the following principles have been considered according to the book entitled "Testing Language Skills from Theory to Practice";

1- Determining the test content

2- Determining the types of the questions in harmony with the content

3 - Determining the number of the questions in every test

Table 3 presents a checklist report of 4 sample accounting ESP final exam test analysis, administered in Accounting Department of Islamic Azad University Shar-e- Rey branch.

TABLE 3

FinAL EXAM TEST EVALUATIONS FOR STUDENTS OF ACCOUNTING

\begin{tabular}{|c|c|c|c|c|}
\hline & Test A & Test B & Test C & Test D \\
\hline $\begin{array}{l}\text { Educational goals } \\
\text { of the test content }\end{array}$ & $\begin{array}{l}\text { Limited focus on morphology } \\
\text { and structure / ESP text } \\
\text { translation skills/ improving } \\
\text { ESP reading texts } \\
\text { comprehension } \\
\text { skills/improving knowledge of } \\
\text { ESP terminology }\end{array}$ & $\begin{array}{l}\text { ESP text translation skills from } \\
\text { English to L1 and vice } \\
\text { versa/limited focus on } \\
\text { improving ESP reading texts } \\
\text { comprehension skills/ } \\
\text { improving knowledge of ESP } \\
\text { terminology }\end{array}$ & $\begin{array}{l}\text { ESP text translation } \\
\text { skills from English to } \\
\text { L1 and vice } \\
\text { versa/improving } \\
\text { knowledge of ESP } \\
\text { terminology }\end{array}$ & $\begin{array}{l}\text { ESP text translation skills } \\
\text { from English to L1 and } \\
\text { vice versa/ on improving } \\
\text { ESP reading texts } \\
\text { comprehension skills }\end{array}$ \\
\hline $\begin{array}{c}\text { Types of } \\
\text { Questions }\end{array}$ & $\begin{array}{l}\text { Limited Focus on definition of } \\
\text { English structure / Translation } \\
\text { of a text into L1/ using the } \\
\text { same text with } 9 \text { multiple } \\
\text { choice items to check reading } \\
\text { comprehension /translation of } \\
\text { technical terminology of } \\
\text { accounting into English }\end{array}$ & $\begin{array}{l}\text { Questions to define technical } \\
\text { terms of accounting in English/ } \\
\text { Translation of a technical text } \\
\text { into L1/Multiple choice } \\
\text { questions to check } \\
\text { comprehension,/cloze test/ } \\
\text { translation of technical } \\
\text { terminology of accounting into } \\
\text { L1 }\end{array}$ & $\begin{array}{c}\text { Translation of a } \\
\text { technical text into L1/ } \\
\text { translation of technical } \\
\text { terminology of } \\
\text { accounting into L1 }\end{array}$ & $\begin{array}{l}\text { Translation of a technical } \\
\text { text into L1/ answering to } \\
\text { technical accounting } \\
\text { questions in English/ Error } \\
\text { correction in English } \\
\text { through technical English } \\
\text { sentences }\end{array}$ \\
\hline $\begin{array}{c}\text { Number of } \\
\text { questions }\end{array}$ & $\begin{array}{l}\text { Translation techniques } \\
\text { ( morphology } 1 \text { question/ } \\
\text { structure } 1 \text { question/ } 1 \\
\text { translation text/ the same text } \\
\text { with } 9 \text { multiple choice items for } \\
\text { comprehension check/ } 12 \\
\text { technical terminologies for } \\
\text { translation }\end{array}$ & $\begin{array}{c}1 \text { question to be defined/ } \\
\text { translation of } 4 \text { technical texts/ } \\
4 \text { multiple choice questions/ } \\
\text { cloze tests with 8gaps / 50 } \\
\text { technical terminologies for } \\
\text { translation }\end{array}$ & $\begin{array}{l}1 \text { question including } \\
\text { translation of } 4 \text { text } \\
\text { out of } 5 \text { presented } \\
\text { technical texts in to } \\
\mathrm{L} 1 / 30 \text { technical } \\
\text { terminologies for } \\
\text { translation }\end{array}$ & $\begin{array}{l}1 \text { question including } 4 \\
\text { technical texts to be } \\
\text { translated into L1/ } \\
\text { answering to technical } \\
\text { accounting questions in } \\
\text { English7 questions/ one } \\
\text { question entailing } \\
\text { technical accounting } \\
\text { sentences for error } \\
\text { correction }\end{array}$ \\
\hline
\end{tabular}

According to the detailed report of the aforementioned checklist, a clear inconsistency among four selected final exam tests can be observed. This has been mainly due to lack of established syllabi for accounting ESP course at this university.

Moreover, the main focus of all the tests have been on translation skills, segregated context free morphological knowledge, and a few structures.

\section{B. Quantitative Phase}




\section{Stage I: Reliability Estimation Report}

At this stage, the reliability of the 4 accounting ESP tests have been measured via KR-21 which has been the most accurate and applicable method as mentioned by Hatch,E., \& Farhady, H.(1981) As it is illustrated in Table 3, the results indicate relatively low reliability estimation for all the tests.

TABLE 3

RELIABILITY ESTIMATION REPORT

\begin{tabular}{|l|l|}
\hline Variables & Percent \\
\hline Test A & $\mathbf{6 0 \%}$ \\
\hline Test B & $\mathbf{6 5 \%}$ \\
\hline Test C & $\mathbf{7 0 \%}$ \\
\hline Test D & $\mathbf{6 8 \%}$ \\
\hline
\end{tabular}

\section{Stage II: Validity Estimation Report}

Validity is arguably the most important criteria for the quality of a test. The term validity refers to whether or not the test measures what it claims to measure. On a test with high validity the items will be closely linked to the test's intended focus. In general, estimating the validity of the tests is measured according to an already standard validated test. However, as there was no standard validated test available to measure in Iran the estimation of the validity was impossible for the present study. In fact this could proof the serious deficiency observed in testing ESP.

\section{CONCLUSION}

In recent decades, teaching ESP in Iran regardless of the deployment of great ESP projects by professionals and pioneers like Dr. Hossein Farhady and his expert team is still in a critical condition. In fact, in the last two decades studying the content of ESP course books from one side and the gap between teaching general English and teaching ESP from another side has led to designing independent and individualized tests (based on every instructor's personal taste) that generally has overlooked the underlying purpose of teaching ESP. In other words, the pioneer Asian countries have attempted to make use of the supportive consultation of ELT experts in designing syllabi, selecting the course syllabi, and designing the university tests through the application of real ESP students' needs analysis procedure. In this regard, in some countries like Japan, South Korea and China the main focus of the designed ESP course books are mainly on the development of four language skills in ESP classes. This product has been the outcome of constructive consultations between ELT experts and ESP professionals. As a result, in the aforementioned countries, the per capita of scientific research, accredited publications, success in developing international academic and science-centered interactions have grown considerable.

In this research project, the principal focus has been concentrated on studying Accounting ESP final exam tests in Islamic Azad University, Shahr-e-Rey branch. Consequently, none of the 4 selected tests were standard nor designed in accordance with a validated standard criterion. In other words, they were merely developed independently and based on individual test developer's (instructor's) personal tastes which reflects on and proves the inconsistency of the syllabi applied in the classes in this department. The results of the present investigation indicate the demand for practical resolutions. Firstly, defining the syllabi and course content for accounting ESP program which are practical, standard, up-to-date, and according to the needs of the target ESP students. The next proposal would be building up a test designer team consisting of both ELT and ESP expert instructors in order to design and develop standard tests which have acceptable reliability and validity for the specific region and students. Finally, building up an audit team to periodically evaluate the administered tests to update and upgrade them to ensure the educational quality of the tests. In conclusion, it is merely through these practical actions that the tests would be so qualified that can guarantee the efficiency of the ESP education at universities.

\section{REFERENCES}

[1] Alderson, J. C., Clapham, C., \& Wall, D. (1995). Language Test Construction and Evaluation. Cambridge: Cambridge University Press.

[2] Bachman, L. F., \& Palmer, A. S. (1996). Language testing in practice. Oxford: Oxford University Press.

[3] Brown, J. D. (1996). Testing in Language Programs. Prentice Hall: USA.

[4] Brown, J. D. \& Rodgers, Th. S. (2009). Doing Second Language Research. Oxford: Oxford University Press.

[5] Douglas, D. (2000). Assessing Languages for Specific Purposes. Cambridge: Cambridge University Press.

[6] Dudley-Evans, T., \& St. John, M. J. (2005). Developments in English for Specific Purposes. Cambridge: Cambridge University Press.

[7] Ellis, R. (2003).Task-based Language Learning and Teaching. Oxford: Oxford University Press.

[8] Hatch,E., \& Farhady, H. (1981). Research design and statistics for applied linguistics. University of California, Los Angles.

[9] Hughes, A. (1989). Testing for Language Teachers. Cambridge: Cambridge University Press.

[10] Hutchinson, T., \& Waters, A. (1987). English for Specific Purposes: A learning-centered Approach. Cambridge: Cambridge University Press.

[11] Hughes, A. (1989). Testing for Language Teachers. Cambridge: Cambridge University Press.

[12] Maxwell, J. A. ( 2005). Qualitative research design: An interpretative approach. (2nd ed.) Thousand Oaks, CA: Sage. 
[13] Mertens, D. M. (2005). Research and evaluation in education and psychology. (2nd ed.) Thousand Oaks, CA: Sage.

[14] Richards, J. C., \& Renandya, W. a. (2002). Methodology in language teaching: An anthology of current practice. Cambridge: Cambridge University Press.

[15] Tomlinson, B. (2003). Developing materials for language learning. Continum: USA.

[16] Tratnik, A. (2008). Key Issues in Testing English for Specific Purposes. Journal of the Slovene Association of LSP Teachers. 4.1, 3-13

Farnaz Latif is a PhD holder in TEFL who graduated from Department of Foreign Langauges, Khorasgan Branch, Islamic Azad University, Isfahan, Iran.At the moment, she is the head of language Department in Islamic Azad University Shahr-e- rey branch, and a General English Course instructor at university. In addition she is supervising and instructing Business English Courses in SAPCO ( an automative part supplier company).She has totally 14 years experience of teaching English in different fields. Her research interests are Teacher Education, ESP, CALL, Materials Development

Mahdieh Shafipoor is a TEFL M.A. holder and a faculty member at Islamic Azad University Shahr-e-Qods branch. She is a lecturer at research, testing, teaching methodology, and contrastive analysis. She also has totally 14 years experience of teaching English in different fields. She has carried out research studies on applied linguistics. Her fields of interest are testing and assessment, syllabus design, and CALL. 